University of Chicago Law School

Chicago Unbound

Journal Articles

Faculty Scholarship

1984

\title{
The Nonprobate Revolution and the Future of the Law of Succession
}

John H. Langbein

Follow this and additional works at: https://chicagounbound.uchicago.edu/journal_articles

Part of the Law Commons

\section{Recommended Citation}

John H. Langbein, "The Nonprobate Revolution and the Future of the Law of Succession," 97 Harvard Law Review 1108 (1984).

This Article is brought to you for free and open access by the Faculty Scholarship at Chicago Unbound. It has been accepted for inclusion in Journal Articles by an authorized administrator of Chicago Unbound. For more information, please contact unbound@law.uchicago.edu. 


\title{
THE NONPROBATE REVOLUTION AND THE FUTURE OF THE LAW OF SUCCESSION
}

\author{
John H. Langbein*
}

The popular demand for probate avoidance has coincided with a fundamental change in the nature of wealth. Most property now takes the form of claims on financial intermediaries, who can easily transfer account balances on death, without court proceedings. Further, creditors have developed a variety of techniques for collecting decedents' debts without probate. Professor Langbein sees in these developments the basis for legitimating the main will substitutes as "nonprobate wills" and for unifying the constructional law of wills and will substitutes.

$\mathrm{O}$ VER the course of the twentieth century, persistent tides of change have been lapping at the once-quiet shores of the law of succession. Probate, our court-operated system for transferring wealth at death, is declining in importance. Institutions that administer noncourt modes of transfer are displacing the probate system. Life insurance companies, pension plan operators, commercial banks, savings banks, investment companies, brokerage houses, stock transfer agents, and a variety of other financial intermediaries are functioning as free-market competitors of the probate system and enabling property to pass on death without probate and without will. The law of wills and the rules of descent no longer govern succession to most of the property of most decedents. Increasingly, probate bears to the actual practice of succession about the relation that bankruptcy bears to enterprise: it is an indispensable institution, but hardly one that everybody need use.

This Article seeks to explain some of the causes and consequences of the nonprobate revolution. Part I describes the major will substitutes, the instruments of the nonprobate system. Part II identifies a pair of central causes of the decline of probate. 1 First, changes in the nature of wealth and in patterns of wealth-holding, especially changes associated with the rise of financial intermediation, have radically diminished the need for title-clearing. Meanwhile, the business practices of lenders have been developing in ways that have stripped the real importance from the creditor protection function of probate.

* Max Pam Professor of American and Foreign Law, University of Chicago.

I wish to acknowledge suggestions and references from Douglas Baird, Walter Blum, Michael Carrico, Charles Donahue, Jr., Richard Epstein, Lawrence Friedman, Mary Ann Glendon, Richard Helmholz, Ian Macneil, Lawrence Waggoner, Richard Wellman, and James Zartman.

1 The term "probate" originally applied only to the proceedings used to prove (probare) a will; it stood in contrast to "administration," which comprehended all subsequent proceedings winding up the estate. In modern American usage, "probate" embraces "administration" and hence extends to the administration of both testate and intestate estates. See, e.g., M. RHEINStein \& M. Glendon, The Law of Decedents' Estates 478 (I97 I). 
These are the underlying forces that have unleashed the will substitutes and made possible the dominance of the nonprobate system.

Part III treats a long-festering problem of legal doctrine: the need to reconcile nonprobate transfers with the supposed monopoly of probate. In order to validate will-like modes of transfer that lack Wills Act formality and that operate without the mechanisms and protections of probate, we have been pretending that the will substitutes are lifetime transfers. In truth, will substitutes are simply "nonprobate wills" - "wills" that need not comply with the Wills Act.

Our preoccupation with denying the will-like character of the will substitutes has distorted legal doctrine on a range of issues. Constructional questions that are functionally identical are now handled under different rubrics, and outcomes differ depending on whether a transfer occurred in a probate or a nonprobate mode. Part IV shows how the recognition of the will-like character of will substitutes can provide a basis for consistent treatment of these construction issues. In place of pointless skirmishing about how to draw the probate/nonprobate line, we can have a unified law of succession.

\section{The Will Substitutes}

Four main will substitutes constitute the core of the nonprobate system: life insurance, pension accounts, joint accounts, and revocable trusts. When properly created, each is functionally indistinguishable from a will - each reserves to the owner complete lifetime dominion, including the power to name and to change beneficiaries until death. These devices I shall call "pure" will substitutes, in contradistinction to "imperfect" will substitutes (primarily joint tenancies), which more closely resemble completed lifetime transfers. The four pure will substitutes may also be described as mass will substitutes: they are marketed by financial intermediaries using standard form instruments with fill-in-the-blank beneficiary designations.

The typical American of middle- or upper-middle-class means employs many will substitutes. The precise mix of will and will substitutes varies with individual circumstances - age, family, employment, wealth, and legal sophistication. ${ }^{2}$ It would not be unusual for someone in mid-life to have a dozen or more will substitutes in force, whether or not he had a will. ${ }^{3}$

2 The number of will substitutes that a person has in force probably declines as he reaches old age. Many life insurance policies expire when an insured leaves employment or attains a certain age. An elderly insured may allow other insurance to lapse because the cost of protection rises steeply while the need to protect dependents ordinarily diminishes. Pension accounts tend to be annuitized or consumed in retirement. Joint accounts are predominantly spousal will substitutes, and the survivor who takes under such arrangements is less likely to create them afresh in widowhood for nonspousal survivors.

${ }^{3}$ A telephone survey of Indiana residents conducted in 1983 under the direction of Professor 


\section{A. Life Insurance}

A propertied person of middle years commonly has several life insurance policies that he has acquired at different times - one or two purchased individually, others obtained as group policies that typically arise out of employment. ${ }^{4}$ The beneficiary designation in a life insurance policy serves precisely the function of the designation of a devisee in a will. The label aside, life insurance is functionally indistinguishable from a will, for it satisfies the twin elements of the definition of a will. We say that a will is revocable until the death of the testator and that the interests of the devisees are ambulatory - that is, nonexistent until the testator's death. ${ }^{5}$ Unless specially restricted by contract, the life insurance beneficiary designation operates identically.

In the I960's, Spencer Kimball wrote about "the close similarity" of the execution of a life insurance beneficiary designation "to the making of a will. . . . Just as the will is 'ambulatory,' taking effect only on death, so the beneficiary designation can be changed until death." 6 Indeed, Kimball said, life insurance was displacing testation:

The only significant assets of the estates of most people are the proceeds of one or more life insurance policies. For such people, constituting a majority of the population, determination of the distribution of that "property" through the designation of a beneficiary under the insurance contract not only has precisely the same function as a will; but constitutes a much more important "testament" than

Michael Carrico of the Indiana University School of Law produced some suggestive data regarding these patterns. The respondents $(242$ in number) were asked whether they had in effect any of five common will substitutes: life insurance, trusts, pensions, joint savings accounts, or P.O.D. ("pay-on-death") bonds. The interviewers recorded the number of types of will substitutes in effect for each respondent, but not the number of instances of each type, because it was discovered "in pretesting [that] many respondents had no idea about how many were in effect and . . . that almost all respondents had great trouble with those questions." Letter from Professor Michael Carrico to the author (Jan. 18, 1984). The results were as follows: $11.2 \%$ of the respondents reported having none of the five types in effect, $15.7 \%$ had one in effect, $38.4 \%$ had two, $27.3 \%$ had three, and $7.4 \%$ had four. Persons with none or only one were disproportionately of the lowest income category (below $\$ 10,000$ per year) and the lowest age group (20 to 29 years old). Id. For a more complete discussion of the survey from which this data derives, see Carrico, Public Knowledge and Attitudes About Property Distributions at Death and Will Substitutes in Indiana, I984 AM. B. Found. RESEARCH J. (forthcoming).

4 See American Council of Life INS., Life INSURANCE FaCt Book 1983 , at $20(1983)$ ("Some 154 million people were insured by some form of life insurance at year-end 1982.").

${ }^{5}$ On the definition of a will, see the main American text, T. AtkInson, HandBook of THE LAW OF WILLS I-3 (2d ed. I953), which follows Jarman, the rgth century English writer, see I T. JARMAN, JARMAN ON WILLS 26 (R. Jennings 8th ed. I95I).

${ }^{6}$ Kimball, The Functions of Designations of Beneficiaries in Modem Life Insurance: U.S.A., in Life Insurance LaW IN INTERnational Perspective 74, 75-76 (J. Hellner \& G. Nord eds. 1969$)$. 
the will. In view of the numbers of people involved, the life insurance beneficiary designation is the principal "last will and testament" of our legal system. ${ }^{7}$

At the end of 1982 , the face amount of life insurance in force in the United States approached four and one-half trillion dollars and averaged over $\$ 57,000$ per insured family; payments on death during the year exceeded fifteen billion dollars. ${ }^{8}$

\section{B. Pension Accounts}

Any American who has spent much time in the work force since World War II is likely to have acquired rights in one or more pension accounts, depending upon his employment history and the features of the plans in force where he has worked. ${ }^{9}$ The tax laws have also been encouraging him to create supplementary retirement accounts, sometimes arranged through his employer, otherwise in the form of IRA accounts or Keogh plans with any of the many financial intermediaries that offer them. ${ }^{10}$ All these pension accounts contain will substitutes - beneficiary designations that pass the owner's interest to the persons of his choice in the event that he dies before exhausting the account in its retirement payout phase. ${ }^{11}$ In I 983 the pension industry journal reckoned that " $[\mathrm{t}] \mathrm{he}$ assets of the nation's non-federal pension plans probably now exceed $\$ \mathrm{I}$ trillion."12

\section{Bank, Brokerage, and Mutual Fund Accounts}

In arranging their personal banking, Americans meet another raft of invitations to execute will substitutes. Married persons in particular elect these options widely. The purest of the bank-operated will substitutes are accounts over which the depositor retains explicit lifetime dominion while designating beneficiaries to take on his death. Where

7 Id. at 76. If Kimball had written this passage in the I980's rather than the I960's, he would have qualified it to reflect the greater prominence of pension assets.

8 AMERICAN CounCIL OF LIFE INS., supra note 4, at 5, 37-38.

9 See Committee for Economic Dev., Reforming Retirement Policies 18 (I98I) ("[T]he proportion of full-time workers in the private nonagricultural sector between 25 and 64 years of age participating in employer pension plans has risen from less than 50 percent in 1957 to more than 75 percent in $\left.1979 .{ }^{2}\right)$.

10 See I Pens. \& Profit Sharing (P-H) ๆf I2,00I-I3,587 (I982-I983).

11 When a plan participant dies before satisfying vesting requirements in a defined-benefit plan, survivorship rights ordinarily perish with retirement rights. Moreover, not all pension plans have survivorship rights. Some government-operated plans feature limited survivorship rights that restrict the participant's choice of beneficiary to certain dependents or (like Social Security) deny him any choice. See Dunham, Sixty Different Succession Laws in Illinois, 46 ILL. B.J. 74I (1958).

12 Pensions \& Investment Age, Apr. 18, 1983, at 10. The same journal computed in the wake of the $1982-1983$ stock market rise that the asset values of the nation's 1,000 largest pension funds had reached $\$ 806$ billion at year-end I983. See id., Jan. 23 , I984, at 3 . 
local law permits, such arrangements may assume the blatant form of the P.O.D. ("pay on death") account, which was pioneered by the United States Treasury for selling government bonds. ${ }^{13}$ Elsewhere, the subterfuge of the Totten trust, discussed below, ${ }^{14}$ allows a functionally identical result.

More commonly, the joint bank account - whether savings or checking - is manipulated to do the work of a will. ${ }^{15}$ In theory, joint accounts differ from other pure will substitutes: they look more like gifts than like wills. When the owner of property arranges to take title jointly, he supposedly creates a present interest in his doneecotenant. In the prototypical joint tenancy of realty, the donee receives an interest equal to the donor's, and the donor loses the power to revoke the transfer. Moreover, the commonality-of-use rule requires that the cotenants act together in order to transfer the realty. ${ }^{16}$ Joint accounts of personalty, however, "differ from the true joint tenancies as defined in [real] property law, for by the privilege of withdrawal either [cotenant] may consume the account."17 Accordingly, a depositor may name a cotenant on a bank account but deal with the account as though it were his own. The cotenant may not even know that he has been designated. Depending on his contract with the bank, the depositor may revoke and alter cotenancy designations as freely as he would beneficiary designations under any of the other will substitutes. He may also achieve the same result by closing the account, withdrawing the funds, and opening another account as he pleases. In this way, joint accounts may be used to approximate the incidents of a will; the cotenancy designation is effectively revocable and ambulatory.

Brokerage houses apply the same mechanism to so-called street accounts. ${ }^{18}$ In an account that is nominally joint, the beneficial owner

13 See generally Annot., 37 A.L.R.2D I22I (1954) (discussing the rights upon death of surviving co-owners of United States bonds).

14 See infra p. I113.

15 See infra note 23 (discussing prevalence of joint ownership). Joint accounts serve more than one purpose. Doubtless the main attraction for spouses is that joint accounts achieve what is in practice an agency or cross-agency arrangement empowering each spouse to draw on the other's funds in the account. Joint accounts have also been employed to avoid guardianship in the event of incapacity. See, e.g., In re Estate of Schneider, 6 Ill. 2d 180, 183, 127 N.E.2d 445, 447 (1955) (holding inference of donative intent rebutted by proof that depositor told cotenant, "I want your name on these bank accounts so that in case I am sick you can go and get the money for me."). It is to be hoped that the spread of modern durable-powers schemes such as UNIF. PROBATE CODE (UPC) $\S \S 5-501$ to -502 (I982) will abate the use of joint accounts as guardianship substitutes.

16 See 2 AMERICAN LAW OF PROPERTY § 6.2 (A. Casner ed. I952).

17 R. Brown, The Law of Personal Property $\S 65$, at 217 (2d ed. 1955) (footnote omitted).

18 An example, the Merrill Lynch account form, is reprinted in Langbein, Substantial Compliance with the Wills Act, 88 HARv. L. REv. 489, 505 n.67 (r975). Securities held in 
of the securities may deal with them as though he has not made the cotenancy designation, but on the owner's death the cotenant succeeds to the securities or other account proceeds. Investment companies have extended the practice to mutual fund accounts, including the hugely successful money market funds of the I970's and x980's.

\section{The Revocable Inter Vivos Trust}

Although the revocable trust is the fundamental device that the estate-planning bar employs to fit the carriage trade with highly individuated instruments, the revocable trust also keeps company with the mass will substitutes. Standard-form revocable trusts with fill-inthe-blank beneficiary designations are widely offered in the banking industry and were at one time aggressively promoted in the mutual fund industry. ${ }^{19}$ The Totten trust, an especially common variant, is simply a deposit account in which the beneficiary designation is thinly camouflaged under language of trust. ${ }^{20}$ The depositor names himself trustee for the beneficiary, but retains lifetime dominion and the power to revoke. The Totten trust, revealingly called the "tentative" trust in the Restatement of Trusts, ${ }^{21}$ has often been referred to as "the poor man's will" (although, as Lawrence Friedman has remarked, the term "middle-class will" would be more accurate ${ }^{22}$ ).

Either by declaration of trust or by transfer to a third-party trustee, the appropriate trust terms can replicate the incidents of a will. The owner who retains both the equitable life interest and the power to alter and revoke the beneficiary designation has used the trust form to achieve the effect of testation. Only nomenclature distinguishes the remainder interest created by such a trust from the mere expectancy arising under a will. Under either the trust or the will, the interest of the beneficiaries is both revocable and ambulatory.

"street name" are registered in the name of the broker (or other intermediary), rather than in the name of the beneficial owner for whose account they are held.

19 The Farkas case dealt with a declaration-of-trust form peddled by a mutual fund sponsor. See Farkas v. Williams, 5 Ill. 2d 4I7, I25 N.E.2d 600 (1955), discussed at infra pp. II26-27. Norman Dacey, who popularized the revocable trust as a device for probate avoidance, see infra p. III6, was a mutual fund salesman. See Grievance Comm. v. Dacey, 154 Conn. I29, 222 A.2d 339 (Ig66).

20 Restatement (SECOND) of Trusts $\$ 58$ (I959).

21 Id. The Uniform Probate Code, which validates P.O.D. accounts, effectively assimilates the Totten trust to the P.O.D. account by spelling out that the trust account "belongs beneficially to the trustee during his lifetime" and to the beneficiary on the 'trustee's death. UPC §\$ 6IO3(c), -IO4(c)(2) (Ig82)." The Totten trust is named after the leading case, In re Totten, I79 N.Y. II, 7 I N.E. 748 (1904), in which the label "tentative trust" also appears, id. at $126,7 \mathrm{I}$ N.E. at 752 .

22 Friedman, The Law of the Living, the Law of the Dead: Property, Succession and Society, Ig66 WIs. L. REv. 340, 369. 


\section{E. Imperfect Will Substitutes}

The "pure" will substitutes are not the only instruments of the nonprobate revolution; "imperfect" will substitutes - most prominent among them the common-law joint tenancy - also serve to transfer property at death without probate. Joint tenancies in real estate and in securities are quite common; joint tenancies in automobiles and other vehicles are also fairly widespread. ${ }^{23}$ Because they ordinarily effect lifetime transfers, joint tenancies are "imperfect" rather than "pure" will substitutes. When the owner of a house, a car, a boat, or a block of IBM common stock arranges to take title jointly, his cotenant acquires an interest that is no longer revocable and ambulatory. Under the governing recording act or stock transfer act, both cotenants must ordinarily join in any subsequent transfer. ${ }^{24}$ Yet like the pure will substitutes, joint tenancy arrangements allow the survivor to obtain marketable title without probate: under joint tenancy, a death certificate rather than a probate decree suffices to transfer title. ${ }^{25}$

People seeking to transfer property at death without using the probate system have thus been tempted to use the common-law joint tenancy as a will substitute notwithstanding its lifetime consequences. This practice has bred a considerable case law treating situations in which the transferor changes his mind and seeks to rescind the transfer. The trend of modern authority is to allow him to unscramble the transaction by proving that he lacked donative intent. ${ }^{26}$ Blanchette v. Blanchette, ${ }^{27}$ a Massachusetts case decided in 1972 , is instructive. Robert Blanchette bought AT\&T stock under an employee stockpurchase plan. He took title to several certificates jointly with his wife Marie in order that, should he predecease her, she would have the stock "without probate or lawyer."28 The marriage later soured and ended in divorce. Robert sued to have himself declared the sole owner of the shares and to obtain a decree ordering Marie to release

23 Empirical studies of joint tenancies, conducted in Iowa in the rg6o's by William Hines, supply some suggestive data. Hines found "that in 1964 an average of 52 per cent of all Iowa land transfers created joint tenancies." Hines, Real Property Joint Tenancies: Law, Fact, and Fancy, 5I IowA L. REv. 582, 587 (I966) (footnote omitted). In a small sample of Iowa households, Hines found astonishing levels of joint tenancy in personalty: about $89 \%$ of checking accounts, $8 \mathrm{I} \%$ of savings accounts and time certificates, $55 \%$ of stock, $72 \%$ of bonds, $39 \%$ of first cars, and $20 \%$ of second cars were jointly held. See Hines, Personal Property Joint Tenancies: More Law, Fact, and Fancy, 54 MiNN. L. REv. 509, 574 (1970).

24 See r F. Christy \& R. APPEL, The Transfer of STOCK $§ 220$, at 15:6-:7 (5th ed. 1975) (stock transfer). Regarding realty, see supra p. III2. The recording act for boats is federal. See 46 U.S.C. $\$ \$ 92 \mathrm{I}-927$ (I976).

25 See, e.g., I F. Christy \& R. APPEI, supra note 24 , $\$ 220$, at I5:7.

$26 \mathrm{See}$, e.g., Blanchette v. Blanchette, 362 Mass. 518, 521, 287 N.E.2d 459, 461 (1972) (collecting cases).

27362 Mass. 518, 287 N.E.2d 459 (1972).

28 Id. at 520,287 N.E.2d at $46 \mathrm{r}$. 
her interest. The Supreme Judicial Court held for Robert on the basis of the trial court's finding that Robert had not created the joint tenancy with donative intent, but solely as a will substitute. ${ }^{29}$

The joint tenancy, although an imperfect will substitute, works well enough in more tranquil family circumstances in which the transferor is not reluctant to part with exclusive lifetime dominion. By providing a nonprobate mode of transfer for realty and securities, the joint tenancy operates in conjunction with the pure will substitutes to make total avoidance of probate feasible for persons of ordinary or even substantial means.

If we were concerned to complete a taxonomy of will substitutes, we could lengthen our list to include devices that are scorned by both lawyers and financial intermediaries but that still attract laymen. A substantial case law chronicles laymen's quixotic attempts to achieve will-like results by manipulating the contingent estates and delivery rules of the law of deeds. ${ }^{30}$ The gift causa mortis is a transparent will substitute, but it can be messy to prove, and it is difficult to keep in force because of the rule that it self-destructs on the donor's return to health. ${ }^{31}$ These and other stray dogs of the American law of gratuitous transfers populate the law school casebooks but have not been quantitatively important in the nonprobate revolution.

\section{The Hidden Causes of the Nonprobate Revolution}

The typical propertied decedent in modern America leaves a will and many will substitutes. The will substitutes differ from the ordinary "last will and testament" in three main ways. First, most will substitutes - but not all - are asset-specific: each deals with a single type of property, be it life insurance proceeds; a bank balance, mutual fund shares, or whatever. ${ }^{32}$ Second, property that passes through a will substitute avoids probate. A financial intermediary ordinarily takes the place of the probate court in effecting the transfer. Third, the formal requirements of the Wills Act $^{33}$ - attestation and so forth — do not govern will substitutes and are not complied with. Of these

29 Such cases can be decided oppositely, of course, when the facts support a finding of donative intent. See, e.g., Clay v. Keiser, 460 Pa. 620, 334 A.2d 263 (I975).

${ }^{30}$ For a recent discussion with citations to earlier literature, see Browder, Giving or Leaving

- What Is a Will?, 75 MicH. L. REv. 845, 860-64 (1977).

31 I W. Bowe \& D. Parker, Page on the LAW of Wills $\S 7.34$, at 338-39 (I960).

32 Revocable inter vivos trusts need not be asset-specific; they can apply, as broadly as a will, to any and all forms of property. The misnamed "cash management account," developed by Merrill Lynch and now widely available in the brokerage industry in joint account form, can also contain a variety of financial instruments.

33 See infra note 68. 
differences, only probate avoidance is a significant advantage that transferors might consciously seek. ${ }^{34}$

No one is surprised that somebody like Robert Blanchette would want to arrange for his wife to succeed to his property "without probate or lawyer." 35 Since the mid-I960's, when Norman Dacey's How to Avoid Probate ${ }^{36}$ ascended the best-seller lists, there has been no denying the depth of public dissatisfaction with probate. ${ }^{37}$ The probate system has earned a lamentable reputation for expense, delay, clumsiness, makework, and worse. In various jurisdictions, especially the dozen-odd that have adopted or imitated the simplified procedures of the Uniform Probate Code of 1969 ("UPC"), the intensity of hostility to probate may have abated a little. There are, however, intrinsic limits to the potential of probate reform. As Richard Wellman, the principal draftsman of the UPC, forthrightly declared: "The assumption that administration of an estate requires a judicial proceeding is as doubtful as it is costly."38 Because the Anglo-American procedural tradition is preoccupied with adversarial and litigational values, ${ }^{39}$ the decision to organize any function as a judicial proceeding is inconsistent with the interests that ordinary people regard as paramount when they think about the transmission of their property at death: dispatch, simplicity, inexpensiveness, privacy. As long as probate reform still

34 The asset-specific quality of the mass will substitutes is a background factor that helps explain the convenience and dispatch of nonprobate transfer. Avoidance of Wills Act formality is incidental to probate avoidance and is not likely to be an important independent desideratum, although some people who are uneasy about dealing with lawyers and legal formality may be more comfortable in the attestation-free, fill-in-the-blank world of the mass will substitutes, which are closer to routine financial transactions.

35 See Blanchette, 362 Mass. at 520, 287 N.E.2d at 461.

36 N. Dacey, How to Avold Probate (I965). Dacey recently published a revision, N. DACEy, How to AVOId Probate - Newly Updated! (2980). For a withering critique in an ABA section journal, see Zartman, How to Void Dacey - 1980, 17 LAW NOTES FOR GEN. PRAC. 73 (r98I).

37 See J. Dukeminier \& S. Johanson, Family Wealth Transactions: Wills, Trusts, AND EstaTES 456-57 (2d ed. I978) (discussing public reaction); Wellman, The Uniform Probate Code: A Possible Answer to Probate Avoidance, 44 IND. L.J. I9I, 192 (1969) (discussing notoricty of Dacey's 1965 publication as well as response of bar and commentators).

38 Wellman, supra note 37 , at 193 .

39 Some wondertul if atypical examples from Georgia law are collected in Bostick, Thte Revocable Trust: A Means of Avoiding Probate in the Small Estate?, 21 U. FLA. L. REv. 44 (ig68):

[P]robate procedures originally designed to assure fair and honest estate settlement . . . today must be regarded as cautious to the point of absurdity. Typical of these procedures is the rule requiring personal service of certain kinds of notice on infant heirs of an estate. In this situation, the serving office[r] or attorney under a strict construction may find himself in the position of actually placing a copy of the legal document in the crib of a small child out of fear that the service may otherwise be inadequate to satisfy the statute. . . E Equally absurd is the statute requiring the attorney or some other representative of the estate to read the contents of a legal advertisement giving notice of intention to sell estate assets from the courthouse steps - often to nonexistent listeners.

Id. at 48 (footnotes omitted). 
calls for probate, ${ }^{40}$ it will not go far enough for the tastes of many transferors, who view probate as little more than a tax imposed for the benefit of court functionaries and lawyers.

The puzzle in the story of the nonprobate revolution is not that transferors should have sought to avoid probate, but rather that other persons whose interests probate was meant to serve - above all, creditors - should have allowed the protections of the probate system to slip away from them. Probate performs three essential functions: (I) making property owned at death marketable again (title-clearing); (2) paying off the decedent's debts (creditor protection); and (3) implementing the decedent's donative intent respecting the property that remains once the claims of creditors have been discharged (distribution). ${ }^{41}$ It is in the sphere of distribution or gratuitous transfer that the will substitutes have proved themselves to be such formidable competitors of the probate system. Although the will substitutes are not well suited to clearing title and protecting creditors, a series of changes in the nature of wealth and in the business practices of creditors has diminished the importance of these functions.

\section{A. Title-Clearing}

The probate court is empowered to transfer title to a decedent's real property and thereby to restore it to marketability under the recording system. The cautious procedures of probate administration have seemed especially appropriate for realty, because the values tend to be large and the financing complex. In theory, the probate court should exercise a similar title-clearing function for all personalty, down to the sugar bowl and the pajamas, because only a court decree can perfect a successor's title in any item of personalty. Of course, ordinary practice quite belies the theory. Beyond the realm of vehicles and registered securities, which are covered by recording systems and thus resemble realty in some of the mechanics of transfer, formal evidence of title is not required to render personalty usable and marketable.

If a decedent's survivors can agree among themselves on a division of his personalty, they can distribute it without court decree. An

\footnotetext{
40 The UPC was amended in 1982 to authorize a version.of the universal successor system of Continental law. See UPC $\S \S 3-312$ to -322 (I982) (succession without administration). It remains to be seen whether American jurisdictions, including states where the pre-1982 UPC is in force, will enact a scheme that finally eliminates mandatory probate.

41 This way of categorizing the functions of probate, while quite conventional, see, e.g., M. RHEINSTEIN \& M. GlendoN, supra note I, at 477 , is not compelled. Another way to conceive of probate is to say that it functions (I) to identify the decedent's rightful successors, and (2) to extinguish competing claims through a variety of means including the discharge of legitimate debts and taxes, the operation of the nonclaim statutes, see infra note 67 , and the adjudication and rejection of unfounded claims. In this way of looking at the process, title-clearing is less an object than an intrinsic byproduct of probate.
} 
empirical study conducted by Allison Dunham in Cook County (Chicago), Mlinois, in the I950's found that about fifteen percent of deaths resulted in probate administration. ${ }^{42}$ Why did the remaining eightyfive percent not require probate? Infants apart, few people are so pauperized that they die owning absolutely nothing. ${ }^{43}$ The reason most deaths do not lead to probate is not that the decedents are propertyless, but simply that they do not own real property (at least not in single tenancy). The survivors can therefore divide up the personalty in a fashion that satisfies those who are entitled to institute probate either under a will or under intestacy. ${ }^{44}$ The legislatures of many states have encouraged this species of probate avoidance through such means as statutes that enable survivors to obtain title to decedents' motor vehicles without probate. ${ }^{45}$

Even real property may pass through nonprobate channels in certain circumstances. When realty is held in joint tenancy, as residential property so often is, ${ }^{46}$ a death certificate alone clears title for the survivor. ${ }^{47}$ Furthermore, there are modes of equitable conveyancing that leave the underlying legal title to the property unaltered and allow a trustee or some similar entity to effect the transfer without probate. Moreover, real estate devoted to entrepreneurial and commercial purposes is increasingly held in corporate form; so, too, is agricultural land, in consequence of the movement to consolidate farms in larger, more capital-intensive units whose financing needs

42 See Dunham, The Method, Process and Frequency of Wealth Transmission at Death, 30 U. CHI. L. REv. 24I, 244 (1963). A study done in the 1960's of testate estates in largely suburban Washtenaw, County (Ann Arbor), Michigan, indicates a comparable level of probates. See Browder, Recent Patterns of Testate Succession in the United States and England, $67 \mathrm{MICH}$. I. REV. I303, I304 (1969). Browder reported 223 testate estates commenced in the year 1963. His study did not require him to compare this figure to the number of deaths for the year. According to data supplied by the Office of the County Clerk, Washtenaw County, there were 2448 deaths in that year; thus, testate estates constituted 9.1\% of the death cohort. Dunham's figure for testate estates in Cook County for 1957 was $8.3 \%$ of the death cohort. See Dunham, supra, at 244. (I wish to acknowledge the kindness of Margaret Thompson and Lawrence Waggoner in obtaining the unpublished Washtenaw County figure for me.)

${ }^{43}$ Most estates are, of course, quite small. Under the federal estate tax law in effect until 1976, which made estates taxable above a $\$ 60,000$ exemption, "only $7 \%$ of decedents each year paid an estate tax." McDaniel, Foreword: The Interaction of Tax Planning and Tax Policy, I9 B.C.L. REv. 387,399 ( 1978 ).

44 I spoke of this phenomenon in Langbein, supra note 18 , at 509 n.85.

45 Statutes commonly authorize state motor vehicle registrars to transfer title to decedents' automobiles without probate decree, merely on affidavit of next-of-kin that the record owner is deceased and that the estate is not being probated. See, e.g., CAL. VEr. CoDE $\$ 59$ Io (West 197I); see also 75 PA. Cons. STAT. ANN. \& III4(b) (Purdon 1977) (authorizing transfer of certificate of title to surviving spouse or spouse's designee on affidavit of surviving spouse that all decedent's debts have been paid).

46 See supra note 23.

${ }^{47}$ See, e.g., Mich. CoMp. Laws \& 565.48 (1979). 
often dictate the corporate form. ${ }^{48}$ Thus, even the family farm, the prototypical object of the probate system, may be transferred outside of the recording system, through the medium of corporation shares.

Nevertheless, real property continues to be the main preserve of probate. Ownership of realty is the factor most likely to determine whether a death will lead to a probate proceeding. Data gathered in the I970's by Robert Stein for an American Bar Foundation study reveals high concentrations of real property in probate estates. About thirty percent of the Maryland probate estates in Stein's sample, over fifty percent of the California estates, and more than eighty percent of the Texas estates contained realty requiring probate. 49

The preoccupation of probate procedure with the transfer of title to single-tenancy real estate reflects the wealth patterns of the smallfarm, small-enterprise economy of the nineteenth century that shaped our probate tradition. "Today's most worrisome and potentially lethal shortcoming of probate," wrote C. Dent Bostick in I968, "is its increasing irrelevance to modern modes of wealth."50 Recall Roscoe Pound's ringing aphorism: "Wealth, in a commercial age, is made up largely of promises." 51 The bulk of modern wealth takes the form of contract rights rather than rights in rem - promises rather than things. The recent boom in residential real estate and collectibles should not obscure this point. Promissory instruments - stocks, bonds, mutual funds, bank deposits, and pension and insurance rights - are the dominant component of today's private wealth. Together with public promises (that is, government transfer payments) these instruments of financial intermediation eclipse realty and tangible personalty.

The instruments of financial intermediation depend upon an underlying administrative capacity that is without counterpart in the realm of realty and tangible personalty. Financial intermediation is, as the term signifies, intrinsically administrative. Administrators intermediate between savers and borrowers, between passive owners and active users of capital. Pooling wealth and servicing the resulting liabilities involves recurrent transactions and communications. Once a bureaucracy appropriate to such tasks is in operation, only a scant adaptation is necessary to extend its functions and procedures to include the transfer of account balances on death.

48 The subchapter $S$ taxation scheme eliminates for many family enterprises the tax disadvantage that would otherwise have impeded the use of the corporate form. See I.R.C. $\$ \S 1361-$ 1379 (1982).

49 Letter from Dean Robert Stein, University of Minnesota Law Schorl, to the author (July 20, 1982) (supplying data).

50 Bostick, supra note 39 , at 46 . Bostick continues: "An abundant concern with real estate title and its protection is reflected in much of modern probate laws . . ." Id.

51 R. Pound, AN INTRoduction to the Philosophy of LAW 236 (1922). 
The probate system nonetheless backstops the practice of financial intermediaries in important ways. The standard form instruments of the nonprobate system all but invariably name the transferor's probate estate as the ultimate contingent beneficiary. If, therefore, the named beneficiaries predecease the transferor or cannot be identified, the financial intermediary remits the fund to probate distribution. Messy heirship determinations are foisted off onto the courts. Likewise, if the proper course of distribution is for some reason doubtful, or if contest threatens, financial intermediaries can force the probate (or other) courts to decide the matter. For example, the intermediary can interplead, or simply refuse suspect claims and force the claimants to sue. ${ }^{52}$ In this way the nonprobate system rides "piggyback" on the probate system. Financial intermediaries execute easy transfers and shunt the hard ones over to probate. But because virtually all transfers are easy, this attribute of the nonprobate system is a major source of its efficiency and comparative advantage. In the nonprobate system, genuine disputes still reach the courts, but routine administration does not.

\section{B. Creditor Protection}

The other set of changes that underlie the nonprobate revolution concerns another great mission of probate: discharging the decedent's debts. Many of the details of American probate procedure, as well as much of its larger structure, would not exist but for the need to identify and pay off creditors. These procedures are indispensable, but - and here I am asserting a proposition that has not been adequately understood - only for the most exceptional cases. In general, creditors do not need or use probate.

I have undertaken to verify this point within the retail and consumer credit industry. ${ }^{53}$ Without mounting a systematic empirical study, I have tried to inquire broadly among credit officers and credit information specialists and their lawyers. Among those I interviewed, I found unanimity both on the central proposition that probate plays an inconsequential role in the collection of decedents' debts, and on the reasons why.

52 See, e.g., Lovell v. Marianna Fed. Sav. \& Loan Ass'n, 264 Ark. 99, 568 S.W.2d 38 (r978) (interpleader); McGee v. St. Francois County Sav. \& Loan Ass'n, 559 S.W.2d I84 (Mo. I977) (suit following bank's refusal to pay).

53 I wish to express my gratitude to the credit-industry and legal professionals who took time to answer my questions, including James Alston, American Express Company; James Matthews, Continental Illinois National Bank and Trust Company; A. Charlene Sullivan, Credit Research Center, Purdue University; James Jurgens and Anne Spioto, First National Bank of Chicago; John Carland, Marshall Field and Company; Lydia Cummings, Hugh Korosec, and Glen Taylor, Montgomery Ward; Stephen Kernkraut, Nancy McCormick, and Gil Wiemers, J.C. Penney; and Shirlee Hoffman, Oscar Marquis, and Stanley Mularz, Trans Union Credit Information Company. 
In the vast majority of cases, survivors pay off decedents' debts voluntarily and rapidly. The chief credit officer of the Marshall Field's department store chain mentioned a particularly telling illustration of this phenomenon. He said that a goodly number of Field's customers were among the 300 victims who died in the DC-Io airliner crash in Chicago in the spring of I979. Within a fortnight of the disaster, the firm began receiving letters from widows, mothers, and other survivors of crash victims, who reported the deaths and either enclosed checks or asked guidance in settling accounts. ${ }^{54}$ Such a mass catastrophe makes the pattern of voluntary assumption and discharge of decedents' debts dramatically visible, but the phenomenon is equally prevalent regardless of the circumstances of death.

Creditors know that survivors behave in this way, and they rely upon voluntary notice from survivors as their primary means of learning about a debtor's death. A credit officer with Montgomery Ward ("Ward's"), the national retail chain, estimated that his firm learned of debtors' deaths from survivors' reports perhaps ninety-five percent of the time. ${ }^{55}$ In the remainder of cases, which usually involve unmarried decedents, the creditor commonly discovers the death when the account becomes delinquent and collections personnel begin making inquiries. None of the large retail creditors with whom I spoke made any effort to take advantage of the formal notice-of-death procedures contained in the probate codes for their protection, nor did they have anyone assigned to read newspaper obituaries or inspect official death registers.

I found the belief widespread among credit industry professionals that voluntary payment is motivated largely by moral as opposed to legal considerations: survivors want to discharge the just debts of decedents, for honor's sake. But many factors bear on this phenomenon, and observers who, unlike me, doubt that ordinary human decency inspires people to act against their economic self-interest can find some comfort in the evidence. Because the account balances in question are often small, honor is relatively inexpensive. For example, at Ward's in June 1983 the average balance outstanding on active accounts was $\$ 470$; at the J.C. Penney chain the figure was a little over $\$ 300 .{ }^{56}$ But these amounts are averages, and millions of accounts run much smaller balances. Indeed, decedents are disproportionately elderly, and the elderly tend to have lower consumption patterns and credit needs than do young families. Although the elderly are major consumers of health care services, decedents' medical debts are largely discharged by third-party payment through the public and private

54 Telephone interview with John Carland, Marshall Field and Company (Nov. 26, I979).

55 Telephone interview with Glen Taylor, Montgomery Ward (June 22, I983).

56 Telephone interview with Nancy McCormick, J.C. Penney (July 8, I983) [hereinafter cited as McCormick interview]; Telephone interview, supra note 55. 
health-insurance systems; and in any event there is unlikely to be a notice problem when a patient dies in his creditor's hands.

When survivors do not pay bank-charge or retail-credit accounts promptly, credit professionals contact them. Appeals to moral instincts are common ("Is it worth soiling your father's reputation in order to deadbeat us out of $\$ 60$ ?") and are widely thought to be effective. In many cases there is also an overlay of legal obligation or economic advantage in a survivor's relationship to an account. Especially among spouses, accounts are often joint; the survivor will have cosigned the account application and accepted joint liability. The threat of credit reporting in such circumstances may have a deterrent effect ("If you deadbeat us for $\$ 60$, you won't be able to get credit from anybody else"). Some account contracts purport to create security interests in all the goods giving rise to the debt, and the threat of repossession can be a source of pressure for payment without court proceedings. Sometimes a survivor has an auxiliary card on a decedent's single-name account, and the decision to pay off the account may be motivated by a desire to retain or convert the account. 57 Many a widow continues her deceased husband's accounts, and only much later, if ever, do the retailers learn of the death.

Creditor protection is also intertwined with a variant of the principal will substitute, life insurance. So-called credit life insurance typically discharges an insured's account balance at death. There are considerable differences in the extent to which various creditors encourage debtors to carry such insurance. At the Continental Bank, I was told, about twenty percent of automobile loans generated by car dealers carried credit life insurance. ${ }^{58}$ Ward's, which operates its own "captive" insurance company and promotes credit insurance through sales literature and other means, has about a third of its active accounts covered. 59 By contrast, J.C. Penney does not offer credit life insurance; and the First National Bank of Chicago, a major operator of bank revolving-credit charge cards (Visa, Mastercard), has experienced negligible enrollment in a credit insurance plan that has not been much promoted. ${ }^{60}$ The American Council of Life Insurance has

57 This practice evokes an echo of one of Stewart Macaulay's findings about why businessmen sometimes operate in disregard of the nominally applicable rules of contract:

Not only do the particular business units in a given exchange want to deal with each other again, they also want to deal with other business units in the future. And the way one behaves in a particular transaction, or a series of transactions, will color his general business reputation.

Macaulay, Non-Contractual Relations in Business: A Preliminary Study, 28 AM. Soc. REv: 55, 64 ( $(963)$.

58 Telephone interview with James Matthews, Continental Illinois National Bank and Trust Company (June 29, I983).

59 Telephone interview, supra note 55 .

60 Telephone interview with Gil Wiemers, J.C. Penney (July 8, I983) [hereinafter cited as Wiemers interview]; Interview with James Jurgens, First National Bank of Chicago, in Chicago (June 15, I983). 
computed that by the end of 1982 more than sixty-six million credit life policies were in force in the United States. More than \$r6r billion in debts were insured; actual benefit payments during the year amounted to $\$ 656$ million. ${ }^{61}$ Of course, credit insurance operates entirely outside probate; most policies are written so that the insurer pays the creditor directly.

Life insurance also figures indirectly in the phenomenon of voluntary discharge of decedents' debts. Most persons of youthful or middle age who qualify for consumer credit are in the work force, and group life insurance is a prevalent employee benefit; further, many persons carry individual coverage. ${ }^{62}$ Insurance proceeds enable survivors to pay the decedent's debts, and because this money derives from the decedent, the moral compulsion to use some of it to clear his debts may be keenly felt.

Toward the upper end of the scale of consumer debt, where we encounter automobile finance, we find a different mode of creditor protection, the security interest. A secured loan gives rise to a recorded lien and a right of the creditor to repossess for delinquency. ${ }^{63}$ This leverage over survivors ordinarily leads to out-of-court settlement of such debts. The survivor assumes or pays off the debt or - less frequently - surrenders the secured asset. Only in the relatively rare case in which the value of the security is inadequate to cover the debt might the creditor need recourse to probate to recover the deficiency. ${ }^{64}$

When this formidable battery of out-of-court payment and collection practices fails to clear a debt, the creditor protection system of probate may also be unavailing. Although the safeguards of notice, court filings, hearings, adjudication, and so forth are meant to protect creditors, they are often self-defeating, because they make probate proceedings too expensive to be cost effective for collecting routine debts. Account balances are often so small that collection costs would exceed the likely recovery even if nonlawyers handled most of the filings and subsequent steps.

Nonetheless, creditors do use probate. The large creditors with whom I spoke were prepared to go to probate to attempt to collect debts of several thousand dollars when preliminary investigation by credit information agencies or in-house personnel revealed the likelihood of substantial assets in a probate estate. None seemed concerned

61 See AMERICAN Council of LIfE INS., supra note 4 , at 32, 39. See generally I ConSUMER CRED. GUIDE (CCH) If 580, Ir20, 5105 (describing.the main features of credit life insurance).

62 See AMERICAN COUNCIL OF LIFE INS., supra note 4, at 28 (indicating that slightly more than two trillion dollars of life insurance in force at year-end 1982 covered employees and dependents under group life policies).

63 See U.C.C. $\$ \S 9-50 I$ to -507 (I977).

64 Likewise, in the realm of real estate finance, the mortgage lender relies all but entirely upon his security interest to protect against default on death, which is why he is indifferent to whether his borrower takes title in the probate-avoiding form of joint tenancy. 
to trace nonprobate assets. All thought that probate filings were of declining cost effectiveness for account balances in the hundreds of dollars, although (perhaps in part in order to maintain credibility in negotiations) American Express and J.C. Penney engage in regular probate filings for sums as low as $\$ 50$ when out-of-court payment cannot be arranged. 65

Thus, when survivors will not acknowledge or pay decedents' debts without court coercion, when survivors cannot pay, or when a decedent's estate is insolvent and apportionment of assets is necessary, creditors still elect their probate remedies if outstanding debts are large enough to justify the expense of the court proceedings. Furthermore, creditors may benefit from the probate system without actually employing it. A creditor's access to the coercive powers of the probate system has a deterrent influence that aids the creditor in his attempts to obtain out-of-court satisfaction from survivors (and from probate representatives - executors and administrators).

The creditor protection procedures of American probate law developed in the nineteenth century to serve needs radically different from today's. By routinizing the process of calculating and evidencing consumer debts, the data processing revolution has virtually eliminated the problem toward which much of the debt-resolving phase of probate procedure has been oriented. Before the refinement and popularization of the corporate form of enterprise organization, personal credit was far more entangled with entrepreneurs' business affairs. Creditor protection mechanisms such as statutory security interests and credit life insurance were primitive or unknown. Communications were slow and unreliable; learning about a death, identifying survivors, and seeking voluntary payment could be difficult and time consuming. Under such circumstances, the alternative of a court-run system of centralized notice and payment channeling appeared more sensible. There was less wealth - much less wealth - and that may have affected the disposition and ability of survivors to pay off debts gratuitously.

In the late twentieth century, creditor protection and probate have largely parted company. Had this development been otherwise, the rise of the will substitutes could not have occurred. If creditors had continued to rely significantly upon probate for the payment of decedents' debts, creditors' interests would have constituted an impossible obstacle to the nonprobate revolution. For - make no mistake about it - the will substitutes do impair the mechanism by which probate protects creditors. Even though the substantive law governing most of the major will substitutes usually recognizes the priority of creditors' claims over the claims of gratuitous transferees (life insurance is some-

${ }^{65} \mathrm{McC}$ Cormick interview, supra note 56; Wiemers interview, supra note 60; Telephone interview with James Alston, American Express Company (July 7, 1983). 
times an exception), ${ }^{66}$ the decentralized procedures of the nonprobate system materially disadvantage creditors. Whereas probate directs all assets and all claimants to a common pot, the nonprobate system disperses assets widely and facilitates transfer without creditors' knowledge. ${ }^{67}$ If modern creditors had needed to use probate very much, they would have applied their considerable political muscle to suppress the nonprobate system. Instead, they have acquiesced without struggle, as have the most powerful of creditor-like agencies, the federal and state revenue authorities.

\section{The Juridical Baśs OF the NonProbate System}

The nonprobate revolution has posed a conceptual problem for the law of wills that is still not cleanly answered in the case law or in the literature: How is it that will-like transfers escape being treated like wills? In the law of wills, the least departure from Wills Act formality ${ }^{68}$ routinely voids the transfer. Yet the will substitutes almost never comply with the attestation requirements for attested wills, nor do they satisfy the handwriting requirement for holographic wills. ${ }^{69}$ What, then, sustains the will substitutes against the Wills Act?

66 On trusts, see 4 A. ScotT, The Law of Trusts $\$ 330.12$, at 26r4-I6 (3d ed. I967); cf. 2 id. § 156 , at $1190-97$ (spendthrift trusts for settlor-beneficiary). On Totten trusts, see I id. $\S 58.5$, at 543-44. On joint bank accounts, see UPC $\S \S 6-107$ to $-\mathrm{II} 3$ (I982). Creditors' rights under state law are expressly preserved by id. § 6-20I(b), discussed at infra pp. II33-34. On life insurance, see $2 \mathrm{~A} \mathrm{~J}$. Appleman \& J. Appleman, INSURANCE LAW AND Practice $\S \S$ I34 $\mathrm{I}-$ $134^{2}$, at $567-86$ (1966).

67 The tendency toward ever-shorter periods for creditor filings in probate (nonclaim periods) is a further symptom of the phenomenon discussed in text. Under the UPC, the nonclaim period can be as short as four months. See UPC $\S 3-803$ (1982). Compare the compilation of American statutes, made a generation ago, of generally longer nonclaim periods. L. SIMEs \& P. Basye, Problems in Probate Law Including a Model Probate Code 325-38 (r946) (six- to twelve-month periods most common).

68 Every Anglo-American jurisdiction has a Wills Act that prescribes the formalities for making an attested will. These statutes have a common core that traces back to English models - the will provisions of the Statute of Frauds of 1677,29 Car. 2, ch. 3, and the Wills Act of 1837, 7 Will. 4 \& I Vict., ch. 26. The terms of the will must be in writing, the testator must sign it, and two (sometimes three) witnesses must attest the testator's signature. Witnesses must be "competent" in the sense of being disinterested. A variety of other requirements can be found in the Wills Acts of different jurisdictions: rules governing the acknowledgment of a signature already in place, rules calling for the testator and the witnesses to sign in each other's presence, requirements about the positioning of signatures, and so forth. In the twenty-odd American jurisdictions that permit holographic wills, the testator may substitute handwriting for attestation. He may execute his will without witnesses if it is "entirely" (or in many states "materially") in his handwriting. The holograph statutes in force as of 1971 are collected and categorized in M. RHEINSTEIN \& M. GLENDON, supra note $I$, at I8I-83. Adoptions of the UPC, which contains a liberal holograph scheme, see UPC § 2-503 (1982) (promulgated in 1969), have added a few more states to the list of those allowing holographs.

${ }^{69}$ The will substitutes would not qualify as wills even if they were executed with formalities satisfying the governing Wills Act, because they lack testamentary intent - that is, intent to 
Our law has dealt with this question by indulging in a pretense - by denying that the will substitutes are will-like and by validating them as gifts. I shall urge a more candid answer, for which I think there is much support in existing practice and doctrine.

\section{A. The Present-Interest Test}

The essential difference between a gift and a will can be simply stated: a gift is a lifetime transfer, ordinarily effected by present delivery of the property, whereas a will transfers property only on the transferor's death. I explained in Part I why the pure will substitutes fall so clearly on the will side of the gift/will line. Each maintains the transferor's complete lifetime dominion and creates no interest in the transferee until the transferor's death. Nevertheless, the case law that has legitimated the pure will substitutes treats them as lifetime transfers. The main stratagem has been to identify some so-called "present interest" in the transferee, acquired during the lifetime of the transferor, which makes the transferee a donee and distinguishes the will substitute from a will.

The leading case exemplifying this mode of analysis is Farkas $v$. Williams, ${ }^{70}$ decided by the Illinois Supreme Court in 1955. Farkas signed four identical fill-in-the-blank declarations of trust supplied by an investment company in connection with his purchase from the company of four blocks of mutual fund shares. He filled in the name of Williams, a faithful employee, as the beneficiary of each trust. The standard form terms reserved to Farkas the right to revoke the trust, to change beneficiaries, and to receive the trust income for life. ${ }^{71}$ If the beneficiary predeceased the testator, the trusts would be automatically revoked. Sale (by redemption) of some or all of the shares would operate as revocation pro tanto. ${ }^{72}$ The declarations were not attested and hence did not conform to the requirements of the local Wills Act. ${ }^{73}$

Farkas died intestate, and his heirs claimed the mutual fund shares for the probate estate. The lower court held in their favor, reasoning that because the beneficiary had had no enforceable interest during Farkas' lifetime, the purported trusts were attempted wills that failed for want of compliance with Wills Act formalities. ${ }^{74}$ The supreme court reversed, concluding that the trusts had created a present interest in the beneficiary. The court conceded that "[i]t is difficult to name

use the probate system. On the requirement that there be testamentary intent independent of formal compliance, see T. ATKINSON, supra note 5, at 205-10.

${ }^{70} 5$ Ill. $2 \mathrm{~d} 4 \mathrm{I} 7$, I25 N.E.2d 600 (I955).

71 See id. at 424, 125 N.E.2d at 604 .

72 See id. at $423-24,125$ N.E.2d at $603-04$.

73 See id. at 421 , 125 N.E.2d at 602.

${ }^{74}$ Farkas v. Williams, 3 Ill. App. 2d 248, 121 N.E.2d 344 (1954). 
this interest"75 but pointed approvingly to a label used in the first Restatement of Trusts, the "contingent equitable interest in remainder."76 How was this remainder evidenced, since the terms of the instrument permitted Farkas both full enjoyment during his lifetime and complete freedom to dispose of the property on death, either by changing trust beneficiaries or by revoking the trusts in whole or in part? The only interest that, according to the court, passed inter vivos to the beneficiary was one in a potential lawsuit: the right to sue the trustee for a breach of some fiduciary duty that impaired the beneficiary's remainder interest. Acknowledging that the beneficiary would never sue during the trustee's life because the trustee could revoke and defeat the claim, the court maintained that the beneficiary could wait for the trustee to die and then sue his estate for the breach of fiduciary duty. ${ }^{77}$

In truth, this ingeniously imagined interest would never be enforceable. In many cases, the estate of the transferor would have a potent defense of laches: the beneficiary's delay in suing to recover for the transferor's supposed breach induced the transferor to leave the trust unrevoked. Even though laches might not defeat the claim of a beneficiary who did not knowingly delay, ${ }^{78}$ success on the merits would be improbable. It is hard to envision what acts of mismanagement might constitute a breach under a trust instrument that expressly immunizes what is normally the most egregious breach a trustee can commit - appropriation of the corpus for his own benefit. The court in Farkas groped for examples of cases in which such liability might arise. Suppose, it said,

without having revoked the trust, Farkas as trustee had given the stock away without receiving any consideration therefor, had pledged the stock improperly for his own personal debt and allowed it to be lost by foreclosure or had exchanged the stock for another security or other worthless property in such manner as to constitute gross impropriety and gross negligence. ${ }^{79}$

The best way to see what is wrong with these examples is to imagine each as a two-step transaction in which the settlor first redeemed the shares and then used the proceeds to commit the act imagined. No liability would result, because the trust explicitly declares that re-

75 Farkas, 5 III. 2 d at 422 , I25 N.E.2d at 603.

76 Id. at 423 , I25 N.E.2d at 604 (citing RESTATEMENT OF TRUSTS $\S 56$ comment $\mathrm{f}$ (I935)).

77 See id. at 432 , I25 N.E.2d at 608.

78 See 3 A. ScoTT, supra note $66, \S 219.4$, at 1763 \& n.3. In the Farkas case, the beneficiary may not have known of the trusts. The settlor signed the declarations of trust and filed them with the investment company. He placed the share certificates issued in his name as trustee in his safe deposit box, where they were found after his death. See Farkas, 5 Ill. 2d at 420, 125 N.E.2d at 602 .

${ }^{79}$ Farkas, 5 Ill. 2d at 432,125 N.E.2d at 608. 
demption is a permitted mode of revocation; and once the transferor had revoked, he would, of course, be entirely free to be reckless with his property. I suggest that if one of the transactions imagined by the court were to occur, the court would treat the case as the analytical equivalent of such a two-step transaction - revocation followed by dealings free of trust. 80 In other words, if a plaintiff brought such a lawsuit - and of course, no one ever has - the estate of the transferor would contend that the interest that the transferor retained under the trust was so great that he owed no duty of care to those to whom he might have left something.

The odor of legal fiction hangs heavily over the present-interest test. We see courts straining to reach right results for wrong reasons and insisting that will-like transfers possess gift-like incidents. Courts have used such doctrinal ruses to validate not only the revocable inter vivos trust, but the other will substitutes as well. Why is a transfer by life insurance policy or by pension plan not void for violation of the Wills Act? Because the beneficiary's interest is "vested" during the transferor's lifetime. But how can it be vested when the transferor may freely revoke the beneficiary's interest? Well, the power to revoke simply makes the interest "vested subject to defeasance." 81 What is the difference between the revocable and ambulatory interest created by a will, and a vested but defeasible interest in life insurance or pension proceeds? None at all, except for the form of words. Similarly, the joint bank account created merely as a probate avoidance device has been treated as a true joint tenancy, despite the depositor's power to exercise total lifetime dominion over the account.82 Of the pure will substitutes, only the transparently labelled P.O.D. account has persistently failed the present-interest test ${ }^{83}$ and has had to depend for the most part upon statutory validation.

80 The court in Farkas employed a similar two-step analysis to explain why a revocable inter vivos trust should be valid even when the settlor retains extensive powers to direct and control the trustee's administration and investment functions: "Actually, any . . . [such] powers could readily be assumed by a settlor with the reserved power of revocation through the simple expedient of revoking the trust, and then, as absolute owner of the subject matter, doing with the property as he chooses." Id. at 430 , I25 N.E.2d at 607 .

81

Some courts have been reluctant to state definitely that the interest of the beneficiary is a mere expectancy where the insured has the power to change the designation and have stated that the interest, in that case; is vested subject to defeasance by the act of the insured. This is a mere nicety of language, comparable with using the right fork or spoon at the table.

2 J. Appleman \& J. Appleman, supra note $66, \S 9 \mathrm{I}$, at 475 (footnote omitted); see also Buehler v. Buehler, 323 S.W.2d 67, 69 (Tex. Civ. App. 1959) (adopting the vested-subject-todivestment formulation to analyze rights in a pension plan).

82 See e.g., Wimmer v. Staver, 218 Wis. II4, 260 N.W. 655 (I935).

83 See, e.g., In re Estate of Atkinson, I75 N.E.2d 548 (Huron County, Ohio, P. Ct. I961). Most courts applied the doctrine of federal supremacy to sustain P.O.D. designations in United States savings bonds, but some jurisdictions resisted that view. See Annot., 37 A.L.R.2D 1221 (1954). 
The lesson of this case law is that the courts sympathize with people who want to avoid probate. As the Massachusetts Supreme Judicial Court said in I944 in one of the most influential discussions of the matter:

If an owner of property can find a means of disposing of it inter vivos that will render a will unnecessary for the accomplishment of his practical purposes, he has a right to employ it. The fact that the motive of a transfer is to obtain the practical advantages of a will without making one is immaterial. ${ }^{84}$

Granting that courts are disposed to favor the will substitutes, the question remains: Why must they couch their support in fiction? Why insist on finding a present interest that is lacking? Why deny the willlike nature of the will substitutes?

\section{B. Probate Monopoly or Transferor's Intent?}

Underlying the case law is the premise that probate is the sole means by which our legal system permits a transferor to pass his property on death. Thus, in the Farkas case the court assumed that Farkas' heirs, his probate takers, would be entitled to the mutual fund shares unless the purported trusts were "present" transfers and hence non-will-like. The assumption that will-like results may be achieved only by instruments that are wills and that invoke the probate system has distorted the law of will substitutes and turned it down the path of fiction. I shall call this assumption the "probate monopoly theory."

The probate monopoly theory purports to derive from the fundamental texts of the law of gratuitous transfers - the Wills Act and the Statute of Descent. Close inspection shows that neither compels it. The typical Wills Act is silent on the question of what transactions it covers - that is, what transfers must take place by will. The Uniform Probate Code, for example, defines "will" in a circular fashion: "Will' includes codicil and any testamentary instrument which merely appoints an executor or revokes or revises another will." 85 Qualifications aside, this definition says that "Will' includes . . . any testamentary instrument" - in short, a will is a will. The Wills Act tells us what formalities are necessary to effect a probate transfer, but it does not purport to forbid or invalidate nonprobate transfers.

A stronger but still unsatisfying linguistic basis for the probate monopoly theory can be found in the Statute of Descent, the law governing succession to any property passing by intestacy. Again we may take the UPC as a fairly typical example: "Any part of the estate of a decedent not effectively disposed of by his will passes to his heirs

\footnotetext{
84 National Shawmut Bank v. Joy, 315 Mass. 457, 47I, 53 N.E.2d rr3, r22 (1944) (citations omitted).

85 UPC § I-20I(48) (I982).
} 
as prescribed in the following sections of this Code." 86 This provision throws us back on the meaning of the term "estate," which is defined unhelpfully as "the property of the decedent." 87 But which property? The probate monopoly theory would require us to read the definition to include property that the decedent meant to pass by will substitute, on the ground that his lifetime dominion made it still his property at death. It is this interpretation that forces the courts to use the lifetime transfer fiction to rescue the will substitutes. But this interpretation is not compelled.

The better solution, which corresponds to modern practice, would be to read "estate" as a residual entity containing only the property not disposed of by will substitute. Such a reading would contradict the probate monopoly theory and make unnecessary the pretense that will substitutes are transfers completed in the lifetime of the transferor. Of course, that interpretation requires a clear understanding of what qualifies as a will substitute. Fortunately, the same.case law that has been so disingenuous in finding fictional present interests has provided a surprisingly candid and functional standard for defining will substitutes.

The courts have been uncomfortable with the present-interest test, and they have attempted to provide a further justification for exempting the will substitutes from the Wills Act - the concept of "alternative formality." In truth, this notion cannot reconcile the.will substitutes with the probate monopoly theory, but it can help us identify the boundaries of the nonprobate system once we reject the probate monopoly theory.

The court in Farkas invoked the alternative formality argument:

Another factor often considered in determining whether an inter vivos trust is [void for violation of the Wills Act] is the formality of the transaction. Historically, the purpose behind the enactment of the statute on wills was the prevention of fraud. The requirement as to witnesses was deemed necessary because a will is ordinarily an expression of the secret wish of the testator, signed out of the presence of all concerned. The possibilities of forgery and fraud are ever present in such situations. Here, Farkas executed four separate applications for stock ... in which he directed that the stock be issued in his name as trustee for Williams, and he executed four separate declarations of trust in which he declared he was holding said stock in trust for Williams. The stock certificates in question were issued in his name as trustee for Williams. He thus manifested his intention in a solemn and formal manner. ${ }^{88}$

${ }^{86} \mathrm{Id}$. $\S$ 2-ror.

87 Id. $\&$ I-2OI(II).

88 Farkas v. Williams, 5 Ill. $2 d{ }_{417}$, 433, 125 N.E.2d 600, 608 (1955) (citations omitted); see supra pp. II26-28. 
Courts and scholars have made the same argument in support of the other main will substitutes. The Totten trust, for example, "is volitional, formal, and solidly backed by business practice." 89 It involves an "interview with the bank officer and the execution of [a] signature card. These procedures would seem to discourage hasty and impulsive action and to reduce the danger of forgery, fraud and coercion to a minimum." 90 In the field of life insurance, the courts treat the "alternative formalities - those formalities required by the contract as a kind of quid pro quo for freedom from the wills statute and probate procedure and costs." 91

The notion of alternative formality offers an important insight. The will substitutes do exhibit formalities - written terms and signature - that parallel the requirements of the Wills Act. And in some cases, the involvement of third parties such as bank officers and insurance agents may serve some of the purposes of attestation. Motivated by considerations of efficiency and accuracy, the financial intermediaries who operate the nonprobate system have developed simplified formalities that largely serve the purposes of the Wills Act. Indeed, the needs of business practice incline the nonprobate system to a level of formality for the will substitutes that is well above the minimum permitted in jurisdictions that allow holographic wills. Holographs get scratched on tractor fenders and bordello walls. ${ }^{92}$ Totten trusts and pension plans do not.

But what, precisely, is the significance of the insight that will substitutes exhibit alternative formality? By emphasizing the functional equivalence of will and will substitute, the notion of alternative formality certainly points us away from the present-interest fiction. Yet this emphasis only deepens our quandary if the probate monopoly theory still holds - if, in other words, all transfer on death must be by will or intestacy. If the Wilks Act governs, the will substitutes are void, because they do not comply with the Wills Act. The transferor is not at liberty to invent alternative formalities for probate transfer, no matter how well they might serve the purposes of the Wills Act. The problem is not that the will substitutes are not formal enough, but simply that their formalities are not those of the statute. Indeed, we can imagine types of noncompliance that exhibit a higher level of formality than the Wills Act requires. Suppose, for instance, that a testator attempted to make his will orally, on videotape, with credible supernumerary witnesses present. No matter how earnest and convincing his expression of testamentary intent might be, and no matter

89 Friedman, supra note 22 , at 369 .

90 Ritchie, What Is a Will?, 49 VA. L. ReV. 759, 763 ( 1963 ).

91 Kimball, supra note 6 , at 77 .

92 For the tractor fender case, see 26 CAN. B. REV. 1242 (I948); for the case of the belly dancer's bedroom wall, see J. DUKEMINIER \& S. JohANSON, stupra note 37 , at 3 ro. 
how superior videotape might be to writing, signature, and attestation for achieving the various purposes of the Wills Act, the testator is not at liberty to enact his own Wills Act. He must comply - at least substantially93 - with the governing Wills Act in order to effect a probate transfer.

Alternative formality is not a test for compliance with the Wills Act; it is a test for not having to comply with the Wills Act. Because it sets limits on what constitutes a valid nonprobate transfer, it gives us a basis other than the probate monopoly theory for resisting claims that casual documents are effective will substitutes. Alternative formality is a test that tells us when a mode of transfer should be fairly regarded as an effective will substitute operating outside the probate system. Alternative formality thus defines the bounds of the nonprobate system.

Modern practice supplies only one theory that can reconcile wills and will substitutes in a workable and honest manner: the rule of transferor's intent. The real state of the law is that the transferor may choose to pass his property on death in either the probate or the nonprobate system or in both. The transferor who takes no steps to form or disclose his intent will be remitted to probate, the state system. The transferor who elects to use any of the devices of the nonprobate system will be protected in his decision, provided that the mode of nonprobate transfer is sufficiently formal to meet the burden of proof on the question of intent to transfer. The alternative formalities of the standard form instruments that serve as mass will substitutes satisfy this requirement so easily that the issue of intent almost never needs to be litigated. The transferor's-intent theory thus replaces the probate monopoly theory. Transferors are free to opt out of probate by selecting any of the well-demarcated nonprobate modes of transfer. ${ }^{94}$

This intent theory supplies the implicit basis for the Uniform Probate Code's article VI, which disavows the present-interest rubric

93 The view that small defects in formal compliance ought not to void a will is one that I have developed in Langbein, Crumbling of the Wills Act: Australians Point the.Way, 65 A.B.A. J. IIg2 (I979), and Langbein, supra note 18. See also R. Wellman, L. Waggoner \& O. Browder, Palmer's Cases and Materials on Trusts and Succession 154-57 (4th ed. 1983) (compendium of the latest developments in legislation and case law concerning the substantial compliance doctrine).

94 Lawrence Friedman made essentially this point in a somewhat different context when he wrote:

In theory, property is legitimately transmitted to the next generation at death only through the medium of a properly executed will or the laws of intestacy. But the "true" rule, implicit in the behavior of courts and legislatures, is quite different. The legal system actually finds acceptable other means of disposing of property at death provided these means are (a) voluntarily adopted by the decedent, and (b) supported by the regularized and formal course of practice of business or social institutions - banks, trust companies, and insurance companies.

Friedman, supra note 22, at 368 . 
and validates the will substitutes wholesale. Article VI contains a group of sections that deal with multiple-party bank accounts ${ }^{95}$ and a general provision, section 6-20I, that covers the rest of the will substitutes. The sections governing bank will substitutes treat the transferor as the exclusive owner of the account during his lifetime but enforce the transfer to the beneficiary on death. ${ }^{96}$ The official comment explains that "a person who deposits funds in a multipleparty account normally does not intend to make an irrevocable gift of all or any part of the funds represented by the deposit." 97 Nevertheless, the Code provides that "the account operates as a valid disposition at death rather than as a present joint tenancy." 98

The UPC's section 6-20I, entitled "Provisions for Payment or Transfer at Death," extends to most of the other mass will substitutes: it brings within its coverage "an insurance policy, contract of employment, bond, mortgage, promissory note, deposit agreement, pension plan, trust agreement, conveyance." 99 For good measure the section lengthens its reach to whatever future products of financial intermediation may emerge: it includes "any other written instrument effective as a contract, gift, conveyance, or trust."100 Each of these will substitutes is declared "nontestamentary," 101 meaning valid though ineffective as a probate transfer under the Wills Act.

The official comment to section 6-20I states flatly that "there appear to be no policy reasons for continuing to treat these varied [will substitutes] as testamentary." 102 By suggesting that there is no ground for interfering with the transferor's choice between probate and nonprobate transfer, the draftsmen are in effect adopting what I have called the transferor's-intent theory. The alternative formalities that characterize the business practice of financial intermediation typically, filling in the blanks on a standard form contract and signing it - are sufficient to evidence intent to transfer the assets in question. The comment continues:

The revocable living trust and the multiple-party bank accounts, as well as the experience with United States government bonds payable on death to named beneficiaries, have demonstrated that the evils

95 UPC $\S \S 6-$ IOI to - Ir 3 (I982). Section 6-IoI(3).extends the scope of these provisions beyond commercial banks to include credit unions and similar deposit takers.

96 See id. \$§ 6-103 to -104.

97 Id. § 6-103 comment.

$98 \mathrm{Id}$.

99 Id. § 6-20I(a).

$100 \mathrm{Id}$. By requiring only a written instrument rather than the writing, signature, and attestation necessary under the Wills Act, the draftsmen may be said to have substituted the level of formality characteristic of the Statute of Frauds for the higher level found in the Wills Act.

$101 \mathrm{UPC}^{\circ} \& 6-201$ (a) (I982).

102 Id. § 6-20I comment. 
envisioned if the statute of wills is not rigidly enforced simply do not materialize. The fact that these provisions often are part of a business transaction and in any event are evidenced by a writing tends to eliminate the danger of "fraud." 103

The UPC has not been adopted widely enough to solve by fiat the problem of the juridical basis of the nonprobate system. ${ }^{104}$ In jurisdictions in which the UPC or similar legislation has not been enacted, the rationale that the UPC supplies for its wholesale legitimation of the will substitutes should guide courts to the same result as a matter of construction of the Wills Act and the Statute of Descent. The UPC disavows the present-interest fiction and recognizes that the will substitutes are transfers on death; it reiterates the declining importance of the protective policy of the Wills Act; and it finds in the alternative formality of the will substitutes further justification for placing nonprobate transfers beyond the reach of the Wills Act and the probate system. ${ }^{105}$ This rationale, as we have seen, is implicit in the case law that developed the alternative formality rubric.

The will substitutes are, of course, secure in American law regardless of theory. Where legislatures have not intervened to immunize the will substitutes, the courts have largely sustained the nonprobate modes of transfer through the lifetime transfer fiction. But fiction has exacted its price. By practicing deception to validate the will substitutes against the probate monopoly theory, the courts have entangled themselves in a web of doctrinal inconsistency on interpretive questions of recurring importance in the law of succession. Understanding the will-like character of the will substitutes is a prerequisite to achieving correct and uniform solutions to functionally identical problems.

\section{UNIFYING THE SUBSIDIARY LAW OF SUCCESSION}

In most fields of law, rules can be divided into two sorts mandatory and subsidiary, jus strictum and jus dispositivum - according to whether they override or yield to the contrary intentions of the parties. In the law of wills, the formal requirements of the Wills Act exemplify mandatory law: the testator is not free to invent

$103 \mathrm{Id}$.

104 The opposition to the UPC has not, however, been directed at article VI, see, e.g., Zartman, An Illinois Critique of the Uniform Probate Code, 1970 U. ILL. L.F. 413, and many jurisdictions have their own legislation protecting various will substitutes from the Wills Act. For recent discussion of New York legislation, see Kane v. Union Mut. Life Ins. Co., 84 A.D.2d 148, 15I, 445 N.Y.S.2d 549, 55 I (198I).

105 For a good illustration of a court's relying upon the alternative formality rubric and making ancillary use of the UPC in a non-UPC state, see Blanchette v. Blanchette, 362 Mass. 518, 524-26, 287 N.E.2d 459, 463-64 (1972); see also supra pp. III4-I5 (discussing case). 
his own formalities. But most rules of the law of wills are rules of subsidiary law that apply only when a will is silent or unclear. Because of the long delay that often intervenes between the writing and implementing of a will, the process of testation invites the creation of subsidiary law. Circumstances often change across the decades in ways that testators. do not address.

A simple example of such a "stale will" situation is that of the testator who gets divorced after writing a will in favor of his spouse. Good divorce lawyers take it as part of their job to see to it that clients revise their wills, but not every client is represented by counsel, much less good counsel, nor do clients inevitably act promptly in accordance with counsel's advice. Suppose, therefore, that John and Mary become divorced and that - months or years later - John dies without having revised a will naming Mary as the primary beneficiary. It can be argued that the will should be enforced as written - indeed, that a testator's will should always be enforced unless and until he revokes it. We are not accustomed to inquiring into the motivations for devises; and in any case, not all divorces are bitter. John may have wished Mary to take under the will notwithstanding the divorce. If John had wanted to condition Mary's devise on the persistence of their marriage, he could have said so in the will. ${ }^{106}$

This position has, however, been decisively rejected in American law. Either by statute or by case law, most of our jurisdictions have reached the result that is codified in the Uniform Probate Code: the divorce extinguishes Mary's interest. ${ }^{107}$ If John wants Mary to take, he must write a new. will or revise the existing will by codicil after the divorce. The premise of the rule is that, because most testators do not want to benefit ex-spouses, such a will no longer reflects the intentions of the testator. Justice will more often be served if divorce is treated as a species of partial revocation and litigation on the question is foreclosed.

What of the will substitutes? Suppose that John had been equally careless in leaving the beneficiary designation in his life insurance policy unaltered. Chances are excellent that Mary would take, unless the language of any marital property settlement between them could be construed to reach the case. An Mlinois court handled one of these cases in the r970's as follows:

Illinois follows the majority rule that a decree of divorce in no way affects the rights of the divorced wife as a beneficiary in a husband's life insurance policy. . . . Surely, if the insured had wished

106 This view was taken in dissent by Judge Leventhal as recently as the mid-rg60's. See Luff v. Luff, 359 F.2d 235, 24I (D.C. Cir. I966) (Leventhal, J., dissenting).

107 See UPC \& 2-508 (1982); Annot., 7I A.L.R.3D 1297 (1976). In some jurisdictions, the presumption of intent to revoke the ex-spouse's devise is rebuttable, see id. at I3II-I7, whereas the presumption is irrebuttable under UPC-type statutes, see id. at 1303-06. 
to substitute another person or his estate as beneficiary following the divorce, he would have at least attempted to effect a change with the insurer or included a provision in the property settlement agreement indicating such intention. ${ }^{108}$

The Illinois case is typical in that the court felt itself under no obligation to mention, much less to reconcile, the contrary rule and rationale of the law of wills. Said another court in one of these divorce/ life insurance cases: "It is settled in New Jersey that a named beneficiary has a vested right to insurance proceeds, subject to divestment according to the terms of the policy." 109 The doctrinal ruse that courts use to escape the probate monopoly theory thus comes back to haunt the law of will substitutes. Because the will substitutes are improperly deemed lifetime transfers, principles of construction and presumptions of transferors' intent that have been developed in the law of wills do not apply.

Even when a court sees the tension between the rule for wills and the contrary rule for will substitutes, the conventional mischaracterization of the will substitutes as lifetime transfers still complicates the remedy. In Miller v. First National Bank \& Trust Co., 110 the transferor set up an inter vivos trust for his wife and named the trust as the beneficiary of his pour-over will. He divorced her and died without amending either instrument. The estate plan would thus have passed the probate assets to the trust, and from there to the ex-spouse. The Oklahoma court applied the doctrine of incorporation by reference in order to treat the trust as though it were part of the will. Accordingly, the local divorce/will statute applied. This use of the doctrine of incorporation was mistaken, of course, because there was no intent to incorporate. The purpose of a pour-over is to avoid including the trust in the probate estate. ${ }^{111}$ The court applied the ill-suited incorporation remedy because it saw no better way to extend the divorce/ will statute to the trust: under the lifetime-transfer theory of will substitutes, the law of wills does not apply.

These cases would often solve themselves if the courts admitted the will-like character of the will substitutes. Transferors use will substitutes to avoid probate, not to avoid the subsidiary law of wills. The subsidiary rules are the -product of centuries of legal experience

108 O'Toole v. Central Laborers' Pension \& Welfare Funds, I2 Ill. App. 3d 995, 997-98, 299 N.E.2d 392, 394 (1973).

${ }^{109}$ Gerhard v. Travelers Ins. Co., I07 N.J. Super. 414, 423, 258 A.2d 724, 729 (Ch. Div. I969).

110637 P.2d 75 (Okla. I98I).

111 As the dissenters in the Miller case pointed out, see 637 P.2d at 79-80 (Hargrave, J., dissenting), the Illinois court had refused remedy in a comparable case for fear that the will substitutes would have to become probate wills: "It is quite clear that such documents are not a part of the probate estate and are not a part of a decedent's will." In re Estate of Meskimen, 39 IIl. 2 d 4I5, 4I7, 235 N.E.2d 6I9, 62I (1968). 
in attempting to discern transferors' wishes and suppress litigation. These rules should be treated as presumptively correct for will substitutes as well as for -wills. Once we understand that will substitutes are nothing more than "nonprobate wills" and that no harm results from admitting that truth, we have no basis for interpreting will substitutes differently from. wills. "Both as a matter of legislative policy and as a principle of judicial construction, we should aspire to uniformity in the subsidiary rules for probate and nonprobate transfers. Even when the subsidiary law of wills has been reduced to statute, it represents a determination about what testators ordinarily intend or would have intended.

To be sure, the financial intermediaries who operate the nonprobate system are careful enough in the wording of their transfer forms that some of the major subsidiary rules would have little applicability to the nonprobate system. These organizations have, for example, been sensitive to the lapse problem. Beneficiary designation forms usually encourage transferors to name contingent beneficiaries, and the forms stipulate payment to the transferor's estate when no beneficiary survives. Accordingly, there would be little occasion to apply the antilapse statute ${ }^{112}$ to the will substitutes. Similarly, the assetspecific character of the major will substitutes greatly lessens the potential for ademption problems, ${ }^{113}$ and the terms of most instruments of transfer eliminate the issue by restricting the beneficiary's interest to the account balance remaining on the transferor's death.

On the other hand, we can point to a variety of situations in which business practice does not correct for the want of uniform subsidiary rules. The policy of the simultaneous death rule; for example, is to implement the presumed intent of the transferor to avoid litigation over the sequence of deaths and to prefer his own contingent beneficiary designations to those of his devisee or intestate taker. ${ }^{114}$ Nonprobate transfers raise identical concerns and demand identical rules. ${ }^{115}$ Likewise, with respect to the status of adopted children in matters of succession, there can be no reason other than oversight for

112 See UPC \& 2-605 (1982).

113 See id. $\$ \S 2-606$ to $-607,-6$ 10.

114 See id. $\$ 2-601$. An identical provision for intestate succession is $\S 2$-ro4. For discussion of the policy, see $i d$. § 2-IO4 comment.

115 The Uniform Simultaneous Death Act applies to nonprobate transfers, but it leaves open the possibility of litigation over the precise sequence of deaths, because it applies only when "there is no sufficient evidence that the persons have died otherwise than simultaneously." Unif. Simultaneous Death Act § I (r940); see, e.g., In re Estate of Bucci, 57 Misc. 2d IOoI, 293 N.Y.S.2d 994 (Sur. Ct. I968) (holding that, although husband and wife died in crash of private airplane, evidence of carbon monoxide solely in wife's blood indicated that wife inhaled furnes from the crash and hence survived husband for brief interval). The UPC undertakes to suppress such litigation by requiring that takers survive the decedent by 120 hours, but the rule applies only to probate property. See UPC § 2-IO4 (I982) (intestacy); id. § 2-60I (testate succession). 
the failure of statutes like section 2-IO9 of the UPC 116 to reach nonprobate transfers. Indeed, Illinois now has a statute that addresses this issue. ${ }^{117}$ The law governing the apportionment of estate taxes between probate and nonprobate assets has been moving strongly toward equal treatment of the two. ${ }^{118}$ In a quite recent development, some courts have sought to extend the law governing will contracts to inter vivos trusts. ${ }^{119}$

The rule forbidding a testator to use his will to alter prior beneficiary designations contained in will substitutes is also premised on the spurious lifetime-transfer theory of will substitutes. For example, in explaining its refusal to give effect to a testator's attempt to change a life insurance beneficiary by will, a New Jersey court drew attention to "the doctrine that a beneficiary has a vested right in the insurance proceeds, subject to divestment." 120 The California Supreme Court pointed to the consequence of this reasoning in an opinion that is still followed: "At death [the insured] no longer has a policy to assign. . . . He cannot then change the beneficiary [by will] because the right of the named beneficiary has vested." 121 Similar utterances abound in cases in which transferors attempt to redirect pension, insurance, bank-account, or trust assets by subsequent will. ${ }^{122}$ If the fiction of lifetime transfer could be candidly rejected, no other policy of consequence would prevent the courts from honoring the transferor's intent. The cases sometimes point to the need to protect financial intermediaries from exposure to double payout, but that concern does

116 UPC \& 2-109 (1982).

${ }^{117}$ Act of Jan. I, 1976, § 2-4, ILL. REV. STAT. ch. IIO I/2, § 2-4 (198I). For an instance in which a state supreme court refused over a strong dissent to apply the probate rule to a trust, see Makoff v. Makoff, 528 P.2d 797 (Utah 1974), which held that an adopted child was not the settlor's issue. For further examples of such litigation decided both ways, see Annot., 86 A.L.R.2D II5 (Ig62).

118 See In re Estate of Rosta, III Ill. App. 3d 786, 444 N.E.2d 704 (1982); Note, Equilable Apportionment of the Federal Estate Tax Liability: The Necessity of Clarifying Legislation, 1979 U. ILL. L.F. 703. The Revised Uniform Estate Tax Apportionment Act apportions federal and state taxes among probate and nonprobate takers in proportion to their shares, unless the will contraindicates. REvised UNIF. ESTATE TAX APPORTIONMENT ACT § 2 (I964).

119 The first case was Reznik v. McKee, 216 Kan. 659, 534 P.2d 243 (1975). An Illinois intermediate court followed the Kansas cases, see Northern Trust Co. v. Tarre, 83 Ill. App. 3d 684, 404 N.E.2d 882 (I980), but the Illinois Supreme Court reversed, mainly on constructional grounds, Northern Trust Co. v. Tarre, 86 Ill. 2d 44I, 427 N.E.2d I2I7 (I98I). The court expressly postponed decision on the question "whether, under proper circumstances, the law relating to joint and mutual wills is applicable to trusts." Id. at 449,427 N.E.2d at 1220.

120 Strohsahl v. Equitable Life Assurance Soc'y of United States, 7 I N.J. Super. 300, 304, I76 A.2d 8I4, 816 (Ch. Div. Ig62).

121 Cook v. Cook, I7 Cal. 2d 639, 646, irI P.2d 322, 327 (r94r), followed in, e.g., Moss v. Warren, 43 Cal. App. 3d 651, 656, II7 Cal. Rptr. 796, 799 (1974).

122 See Annot., 25 A.L. R. 4 TH II64 (I983) (life insurance); Annot., 8I A.L.R.3D 959 (1977) (trust); Annot., 46 A.L.R.3D 487 (I972) (Totten trust); Annot., 5 A.L.R.3D 644 (Ig66) (public pension rights). The rule criticized in text is codified in the UPC for joint ("multiple party") accounts. UPC § 6-IO4(e) (1982). The official comment mentions no rationale. 
not justify the rule. Stakeholder protection can easily be achieved by less intrusive means. The rule should be that when a financial intermediary pays the beneficiary named in the designation in its file, the intermediary is protected as long as it lacked notice of a contrary disposition by will. If a mistaken payment occurred, routine restitution law would make the recipient liable to disgorge it to the intended beneficiary named in the subsequent will. ${ }^{123}$

The lifetime-transfer theory of the will substitutes has certainly not been the only cause of the doctrinal disharmony in our treatment of probate and nonprobate transfers. The courts have had to work with legislation that predates or is otherwise insensitive to the consequences of the nonprobate revolution. The rules of subsidiary law have too often been codified in statutes that speak only to probate transfers. Even the enlightened Uniform Probate Code is, as its name indicates, a probate code, not a succession code. It is a product of its day - the I960's - when the reform of probate administration was the draftsmen's overriding concern. Article VI of the UPC treats the will substitutes ${ }^{124}$ for relatively limited purposes - validating them against the probate monopoly theory and sorting out the lifetime rights of transferors in multiple-party accounts. The draftsmen did not have it on their agenda to unify the subsidiary law of probate and nonprobate transfers. Nevertheless, in the realm of mandatory law, the UPC provides a dramatic example of the integration of probate and nonprobate transfers. The UPC's forced-share scheme, ${ }^{125}$ which is patterned on New York legislation, ${ }^{126}$ extends the spouse's elective share to virtually all the will substitutes, and it charges probate and nonprobate assets in proportion to their value. These modern forced-share schemes take their inspiration from the federal transfer-tax rules, which obliterate the probate/nonprobate line for purposes of determining what transfers should be subject to estate taxation. ${ }^{127}$

Having sketched a unified approach to questions of subsidiary law, I must emphasize an intrinsic limit. When a rule of the law of wills is premised on the requirements of Wills Act formality, the unified approach should no longer pertain, because the Wills Act does not govern the will substitutes. Perhaps the best example is the rule forbidding reformation of wills on the ground of mistake - when, for example, a typist drops or garbles a paragraph. The courts have feared that remedying such mistakes would require that unattested language be interpolated in violation of the requirements of the Wills

123 See REstatement of Restitution \$ 204 (1937).

124 See supra pp. Ir $33-34$.

125 UPC $\$ \$ 2-202,-207$ (I982). The UPC is equally comprehensive in treating the effect of homicide by a beneficiary. Id. $\$ 2-803$. The UPC's pretermission rules in $\$ \S 2-301(2)$ and 2$302(a)(3)$ also take some account of "transfer outside the will."

126 See N.Y. Est. Powers \& TRuSTS LAW $\S$ 5-I.I (McKinney I98I \& Supp. I982).

127 I.R.C. $\$ \S 2036-2038$ (Ig82). 
Act. In the law of will substitutes, the courts have wisely permitted such mistakes to be corrected when a high standard of proof can be satisfied. 128

In European law, survivors settle decedents' estates without court involvement unless there is contest or special difficulty. ${ }^{129}$ Our nonprobate system has made it possible for Americans to achieve a similar result, but at a price. Because American law has defined testation and probate in terms of each other, we have had to sacrifice some of the benefits of testation in order to escape probate. The doctrinal disharmony in the subsidiary law of succession can be cured. Unifying the rules of subsidiary law will not, however, restore the inherent unity of the estate plan in a wealth transfer process in which testation governs substantially all of a decedent's property.

In the wake of the nonprobate revolution, a decedent now effects many wealth transfers at death, through instruments that have been executed at different times and that may reflect different circumstances of family and property. As these circumstances change, there is considerable danger that the transferor may neglect to update one or more components of an estate that involves numerous instruments and institutions of transfer. This fragmentation of decedents' estates requires that lawyers practicing in the field of estate planning look beyond probate property. In late-twentieth-century America, it is not enough simply to write someone a will. The client now has many "nonprobate wills" that the draftsman must consider and sometimes revise when drawing up the "probate will."

\section{CONCLUSION}

The nonprobate revolution is a benign and irreversible development. Free-market competitors have relegated probate to the periphery of the succession process. This Article has undertaken to explain how the business practice of financial intermediaries has rendered probate so often superfluous. But legal doctrine has not caught up with this great transformation in the practice of succession. Courts have dressed up the will substitutes as lifetime transfers in order to avoid conflict with the probate monopoly theory of wealth transmission on death. This theory is fundamentally mistaken and should be discarded. The law would function better if it admitted that will

128 See Langbein \& Waggoner, Reformation of Wills on the Ground of Mistake: Change of Direction in American Law?, I30 U. PA. L. REV. 52I, 524-26 (1982). Waggoner and I have criticized the rule forbidding reformation of mistaken wills as a misapplication of the Wills Act, but that is quite beside the present point, which is that, even if the courts continue to apply the rule to wills, there is no basis for extending it to non-Wills-Act transfers.

129 For an English-language discussion, see H. EMMERICH, EsTATE PrACTICE IN THE UNITED STATES AND IN EUROPE I6-I8 (I950). 
substitutes are simply "nonprobate wills." The inconsistent treatment of identical interpretive questions raised by wills and will substitutes is often linked to the mischaracterization of will substitutes as lifetime transfers. The law of wills has reached sound solutions to these interpretive questions, and I have urged that these solutions should extend presumptively to the will-like transfers of the nonprobate system. The result would be a unified American law of succession. 